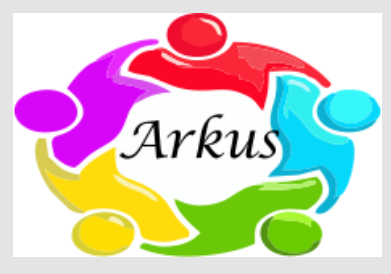

\title{
ARKUS
}

Journal Homepage:

https://hmpublisher.com/index.php/arkus

\section{Client Server Based Integrated School System Design and Implementation}

\section{Fauzi Natsir ${ }^{1^{*}}$}

${ }^{1}$ Informatics Engineering Major, Universitas Islam Negeri Alauddin, Makasar, Indonesia

\section{A R T I C L E I N F O \\ Keywords: \\ Integrated school system \\ Client server based \\ Library \\ Internet \\ Data management \\ Corresponding author: \\ M. Fauzi Natsir \\ E-mail address: \\ fauzinnatsir@gmail.com}

The author has reviewed and approved the final version of the manuscript.

https://doi.org/10.37275/arkus.v6i2.85

\begin{abstract}
A B S T R A C T
The integrated school system is an application intended to process school data, such as processing student re-registration data, student attendance data, and student payment data. This data is not yet optimal, causing difficulties in finding information about student data and making reports that are not adequate. Therefore, an application that can support and solve these problems is needed. This application is built using the Apache webserver as the web server, using PHP as the programming language, and MySQL in database development. This study aims to design an integrated school system at SMAN 9 Makassar based on client-server. The type of research used is quantitative research, while data collection uses library research methods and field research (observation). The testing method uses black box testing, which focuses on the functional requirements of the software. With the integrated school system at SMAN 9 Makassar based on client-server, it can help staff and employees at SMAN 9 Makassar in terms of managing data related to the school. For example, in managing academic data, finance, libraries, personnel, teacher info, student info, and counseling agency.
\end{abstract}

\section{Introduction}

Information technology is currently developing so rapidly. Various information system applications enable fast processing of data and reports. Nowadays, we are used to processing data electronically, automating office work, and digital telecommunications. ${ }^{1}$ The variety of uses of technology has changed all areas of life, including the world of education. In the world of education in Indonesia, computers have been introduced and used in schools ranging from primary education to higher education. Even for education in big cities, computers have been introduced since children enter kindergarten or playgroups to play and learn. Besides being used as a tool for interactive learning, it is audio-visual to facilitate the learning process. With computers, it is easy to find and provide learning materials, for example, with the concept of an electronic library (e-library) or electronic book (ebook). Coupled with the internet, it is possible to search for library collections in books, modules, journals, papers, magazines, and newspapers. Even now, learning can be done via the internet or some open university. Students can learn through books or modules presented attractively either in the form of text or audio-visual presented via the internet. Even with the internet, every student or student can 
communicate via e-mail and interact directly by teleconferencing or video conferencing. Schools must be able to provide the best service to students and parents. Information about the teaching and learning process and its development must be received by students and parents appropriately, quickly, and accurately. The faster information reaches students and parents, the faster the quality of student education will be improved. To be able to provide accurate, fast, and accurate information, schools need an integrated quality school management information system. ${ }^{2-6}$

\section{Methods}

The research was conducted at the SMAN 9 Makassar. The type of research that the author uses is descriptive qualitative research, a type of research whose findings are not obtained through statistical procedures or other forms of calculation but research based on facts or phenomena encountered in the research field. The author's data collection method is by: a. Library research, namely collecting data from various literature related to research, citing expert opinions from reading books related to the discussion of this research, and collecting articles from the internet related to research. b. Field research or field research, namely collecting data by conducting research directly at the research place that has been determined to obtain the data needed as material for discussion in this paper and in collecting data with field research, the author uses three methods, namely: 1) Sampling and investigation, namely by ask for sample samples for documents used by the company concerned with the problem under study. 2) Observation: making direct observations at the research location on the object to be studied and discussed and collecting as much data or information as possible related to the problem. 3) Interview, namely by asking several questions related to the topics discussed to the parties concerned. Program Testing Method is intended to determine whether the software created has met the objectives of the software design itself and shows that the designed application has reasonable quality assurance. The testing method used in this study is Black Box Testing. This testing method focuses on the functional requirements of the software and allows the designer to obtain a set of input conditions that thoroughly test all functional requirements of a program.

The tools and materials needed in this study are as follows: Hardware specifications to be built are divided into hardware specifications for servers and hardware specifications for clients. Hardware specifications for servers: processor for servers at least Pentium IV, server memory at least 256 RAM, server hard disk minimum 40 GB, Monitor 15 ', Mouse, and Keyboard. Hardware specifications for clients: Processor for clients at least Pentium IV, Memory at least 128 RAM, hard disk client at least 10 GB, monitor 15', mouse, keyboard, and printer.

Testing method is intended to determine whether the software created has met the objectives of the software design itself and shows that the designed application has reasonable quality assurance. The testing method used in this study is black box testing, where this testing method focuses on the functional requirements of the software and allows the designer to obtain a set of input conditions that thoroughly test all functional requirements of a program.

\section{Results and Discussion}

A flow map is a map that shows the flow in the program or system procedures logically. The flow map is part of the information that explains the processes of the information system. Considering that humans are the main subject and the main object for the development and development of education, a school information system (SIS) is a vital factor for fast, precise, and effective information. SIS is a comprehensively integrated school system covering 
all school components and data systems both physically and in applications. With this school information system, all integrated reports about schools that are real-time will be created for school policy decision-makers. Based on the ongoing system analysis regarding student data processing and value processing, the authors provide a problem-solving solution by designing a computerized system. In addition to changes to the school system, it is hoped that changes will also occur in the way employees work and knowledge about the new system so that it does not cause other problems in the future. Based on the above, a system is designed to facilitate users who use it to manage data. So that data collection and data retrieval can be done quickly.7,8

Educational institutions have a vital role in producing quality human resources that can compete in the era of globalization and free trade. To form quality human resources requires a quality education service system. For that, all parties involved in the world of education, the central government, regional governments, education personnel, and the community, must work together to improve the quality of education. Schools must be able to provide the best service to students and parents. Information about the teaching and learning process and its development must be received by students and parents appropriately, quickly, and accurately. The faster information reaches students and parents, the faster the quality of student education will be improved. To provide accurate, fast, and accurate information, schools need an integrated quality school information system. To get an integrated school information system that is integrated is not enough to do it manually.

The development of a computer-based management information system is one of the right solutions. From the results of the analysis on the system that is running and the problems that are being faced, the authors propose a solution to the problem on the system that is currently running, namely changing the system that is still manual and replacing it with a computerized system that can undoubtedly process data faster than the manual process. The computerized system is expected to have a positive impact on the progress of education in schools. In addition to changes to the school system, it is hoped that changes will also occur in the way employees work and knowledge about the new system so that it does not cause other problems in the future. Considering that humans are the main subject and the main object for the development and development of education, a school information system (SIS) is a vital factor for fast, precise, and practical information. SIS is a comprehensively integrated school system covering all school components and data systems both physically and in applications. With this school information system, all integrated reports about schools that are real-time will be created for school policy decision-makers. ${ }^{9,11}$

The program structure includes input, process, and output. The data that becomes input are academic, student info, teacher info, financial, library, counseling data (BK), and staffing data. The process of the application consists of creating student data (add, view, edit, delete students), creating teacher data (add, view, edit, delete teacher), and creating library data (add, view, edit delete library), create subject data (add, view, edit, delete, folder), create schedule data (add, view, edit, delete schedule), create value data (add, view, edit, print, delete values), create employee data (add, view, edit, delete employee), create financial data (add, view, edit, delete finance), create presence data (add, view, edit, delete presence). The application's output consists of grade reports, folders and schedules, receipts and expenditure reports, financial transaction reports, returns reports, book receipts and fines, student violations reports, attendance reports, and recapitulation reports. ${ }^{12}$

The menu structure consists of master (academic, finance, teacher info, student info, counseling board, 
library, and personnel), activities (academic data, financial data, teacher data, student data, counseling agency data, borrowing and returning data, employee data, data receipts and expenditures, and data grades, schedules and subjects), reports (receipts and expenses reports, financial transaction reports, student violation reports, acceptance reports, returns and book fines, attendance reports, grade reports, schedules and subjects and reports recapitulation, reports and settings (user access rights, change password, query error log).13,14

\section{Conclusion}

The Client-Server-based Integrated School Information System makes it easy for users to manage the system because it is designed with icons and dialog placement. The system process flow is clear, making it easier for users to manage the contents of this information system. This system also makes it easier for users (parents and the public) to search for information related to their children. Users can also freely submit constructive criticism and suggestions for schools. The integrated school information system makes it easier for teachers and students to carry out the teaching and learning process, especially in this case, sending student assignments through this information system. The existence of a correction system so that this information system can be evaluated for its existence, in this case, facilitates access to information related to the school.

\section{References}

1. Al-Fatta, Hanif, Analisis dan Perancangan Sistem Informasi, Yogyakarta : Andi, 2007.

2. Daryanto, Kamus Bahasa Indonesia Lengkap, Surabaya : Apollo, 1997.
3. Departemen Agama RI, Kandungan Ayat AlAlaq 1-5 Jakarta: 1988.

4. FitzGerald, Jerry et al. Fundamentals of Systems Analysis. Edisi kedua; New York: John Willey \& Sons, 1981.

5. Hartomo, Djoko, Sistem Basis Data, Yogyakarta: Graha Ilmu, 2005.

6. Husein, Muhammad Fakhri, Amin Wibowo, Sistem Informasi Manajemen, Yogyakarta : UPP AMP YKPN, 2000.

7. Jogiyanto, Analisis dan Desain, Yogyakarta : Andi, 2005.

8. Kadir, Abdul, Pemrograman WEB Mencakup: HTML, CSS, JavaScript \& PHP, Yogyakarta : Andi, 2003

9. MADCOM, Aplikasi Manajemen Database Pendidikan Berbasis Web dengan PHP dan MySQL, Yogyakarta : Andi. 2007.

10. Nugroho, Bunafit, Instalasi \& Konfigurasi Jaringan Windows dan Linux, Yogyakarta: Andi, 2005.

11. Oetomo, Budi Sutedjo Dharma. Konsep \& Perancangan Jaringan Komputer. Yogyakarta: Andi, 2004.

12. Peranginangin, Kasiman. Aplikasi WEB dengan PHP dan MySQL. Yogyakarta: C.V Andi Offset, 2006.

13. Prasetyo, Didik dwi. Belajar Sendiri Aplikasi Database Client/Server menggunakan Delphi dan MySQL. Jakarta: PT Elex Media Komputindo, 2004.

14. Pressman, Roger S, Rekayasa Perangkat Lunak: pendekatan praktisi (Buku I), Yogyakarta: Andi, 2002. 